\title{
PELATIHAN PENULISAN KARYA ILMIAH BAGI TENDIK BERBASIS APLIKASI DI KOTA SUNGAI PENUH
}

\author{
Apdelmi $^{1 *}$, Helty $^{2}, \&$ Wawan Junresti Daya ${ }^{3}$ \\ 1,2,3 Fakultas Keguruan dan Ilmu Pendidikan, Universitas Jambi \\ Jl. Jambi-Muara Bulian KM 15, Mendalo Darat, Jambi Luar Kota, Jambi, Indonesia \\ *Korespondensi: apdelmi.fkip@unja.ac.id
}

\begin{abstract}
Abstrak
Penulisan karya ilmiah bagi tenaga pendidik bermanfaat bagi pengembangan keterampilan menulis, peningkatan wawasan dan pengetahuan sesuai dengan bidang keahliannya, serta dapat memajukan kesejahteraan guru. Membuat tulisan yang bersifat ilmiah menjadi salah satu syarat untuk jenjang kepangkatan guru dan sertifikasi guru. Namun, gairah untuk menulis karya tulis ilmiah bagi tenaga pendidik masih rendah. Demikian yang terjadi di Kota Sungai Penuh. Hal ini terlihat dari masih kurangnya tulisan-tulisan tenaga pendidik pada media ilmiah. Kurangnya minat tersebut diduga disebabkan masih kurangnya pengetahuan dan minimnya pelatihan dalam menulis karya tulis ilmiah, untuk itu perlu dilakukan pelatihan penulisan karya ilmiah terutama yang berbasis aplikasi di Kota Sungai Penuh. Hasil kegiatan menunjukkan bahwa dengan dilakukannya pelatihan pembuatan karya tulis ilmiah memberikan kesan baru pada para tenaga pendidik, terutama guru di Kota Sungai Penuh bahwa menulis tidak lah sesulit yang dibayangkan, guru menjadi termotivasi dan mau mencoba menulis, guru juga mendapat ide-ide baru tentang tema-tema yang bisa dikembangkan untuk menjadi karya tulis ilmiah.
\end{abstract}

Kata kunci: PPM, pelatihan karya ilmiah, tenaga pendidik

\section{ANALISIS SITUASI}

Guru sebagai tenaga pendidik, penggerak kemajuan bangsa memiliki peran penting dalam dunia pendidikan. Tenaga pendidik dituntut untuk terus maju, berinovasi mengikuti arus globalisasi dan mengembangkan keprofesionalismeannya (Slamet, \& Deraman, 2008). Pengembangan profesi guru sebagai pendidik bertujuan untuk menciptakan guru yang profesional dalam menjalankan tupoksinya sebagai tenaga pendidik. Hal yang dapat dilakukan untuk mengembangkan profesi tenaga pendidik adalah melalui pembuatan karya ilmiah (Murdick., Ross \& Claggett, 1996).

Karya tulis ilmiah diartikan sebagai hasil karya tulisan yang penyajian nya dalam bentuk tulisan ilmiah dan kemudian disampaikan pada forum atau media yang bersifat ilmiah. Penulisan karya ilmiah bagi tenaga pendidik bermanfaat bagi 
pengembangan keterampilan menulis, peningkatan wawasan dan pengetahuan sesuai dengan bidang keahliannya (Levin, 1983). Membut tulisan ilmiah selain meningkatkan dan mengembangkan keterampilan dan kemahiran guru, juga dapat memajukan kesejahteraan guru. Membuat tulisan yang bersifat ilmiah menjadi salah satu syarat untuk jenjang kepangkatan guru dan sertifikasi guru (Dwiyanto dkk. 2002).

Karya tulis ilmiah bagi tenaga pendidik terdiri dari berbagai jenis di antaranya, berupa hasil pengkajian, berupa gagasan pribadi mengenai dunia pendidikan, tulisan populer untuk media massa, karya berupa buku dan lain sebagainya (Levin dan Schütze, 1983). Karya tulis ilmiah tersebut memiliki angka kredit masing-masing. Semakin mahir seorang tenaga pendidik membuat sebuah karya tulis ilmiah maka diharapkan selain pengetahuan dan keterampilan, kesejahteraannya pun turut meningkat (Jasperson, Carter \& Zmud, 2005).

Saat ini, jika dikaji gairah untuk menulis karya tulis ilmiah bagi tenaga pendidik masih rendah (Nurkolis, 2003). Demikian yang terjadi di Kota Sungai Penuh. Hal ini terlihat dari masih kurangnya tulisan-tulisan tenaga pendidik pada media ilmiah. Kurangnya minat tersebut diduga disebabkan masih kurangnya pengetahuan dan minimnya pelatihan dalam menulis karya tulis ilmiah, untuk itu perlu dilakukan pelatihan penulisan karya ilmiah terutama yang berbasis aplikasi di Kota Sungai Penuh.

\section{METODE PELAKSANAAN}

Metode pendekatan yang dilakukan oleh tim PPM bersama mitra di Kota Sungai Penuh adalah sebagai berikut:

a. Menentukan aplikasi yang akan digunakan dalam pelatihan

b. Menyusun draft pelatihan dan membuatnya dalam slide presentasi

c. Evaluasi pasca pelatihan (Bhargava, Dubelaar \& Ramaswami, 1994).

Adapun tahapan dari kegiatan pengabdian ini yang bermitra dengan Kota Sungai Penuh tediri dari empat tahap, yaitu:

a. pengurusan izin pelaksanaan PPM kepada Dinas terkait

b. pembahasan rencana dan langkah yang akan dilakukan terkait kegiatan PPM bersama mitra

c. pelaksanaan kegiatan sesuai jadwal yang telah disepakati

d. evaluasi pasca kegiatan untuk melihat pengaruh pelatihan dan sejauh apa pemanfaatannya serta apa saja hambatannya 


\section{PELAKSANAAN DAN HASIL}

Hasil pelaksanaan kegiatan Pengabdian Pada Masyarakat (PPM) yang berasal dari Universitas Jambi berjalan dengan lancar meskipun dihadiri oleh peserta yang terbatas pada situasi pandemi ini, peserta pelatihan tampak antusias karena mereka merasa berterima kasih sekali Tim PPM yang berasal dari UNJA mau menyempatkan diri untuk memberikan pelatihan kepada para guru di Kota Sungai Penuh.

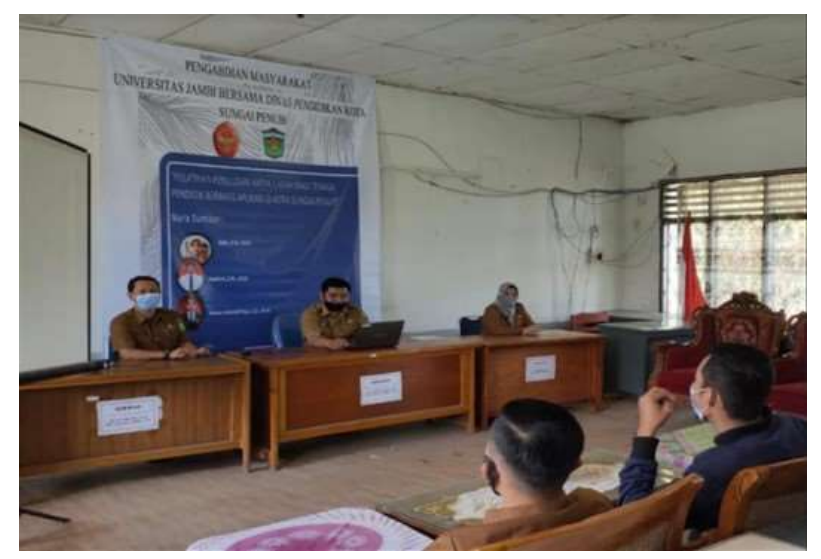

Gambar 1. Penyampaian Materi

Sumber: Dokumentasi kegiatan pengabdian, 2020

Kegiatan pelatihan penulisan karya ilmiah adalah bentuk pengembangan dan profesionalisme guru. Kegiatan ini penting karena selain sebagai pengembangan diri penulisan karya ilmiah merupakan salah satu syarat kenaikan pangkat bagi guru.

Kegiatan ini dibagi menjadi beberapa tahapan. Kegiatan diawali dengan pemaparan materi oleh tim pengabdian mengenai kode etik dalam penulisan karya ilmiah, tata bahasa yang baik, teknik memilih judul, membuat abstrak dan memilih key word. Selanjutnya dilanjutkan dengan pelatihan penyusunan karya ilmiah dalam hal ini adalah PTK. Tim pengabdian mendampingi dan membimbing guru meyusun PTK yang telah dipilih oleh masing-masing guru. Tidak hanya mendampingi penyusunan PTK, tim pengabdian juga membuka ruang diskusi terkait dengan permasalahanpermasalahan yang dihadapi guru dalam membuat karya tulis ilmiah.

Pada akhir kegiatan peserta diminta saling bertukar karya ilmiah dan kemudian memberikan masukan atas karya ilmiah yang telah disusun oleh masing-masing peserta. Hal ini untuk mendapatkan masukan dan umpan balik dari masing-masing peserta. Selain itu para tim pengabdian juga memberikan masukan tentang kelebihan dan kekurangan karya ilmiah yang telah disusun tersebut. Dengan adanya masukan baik dari peserta maupun tim pengabdian, peserta lebih memahami bagaimana 
menyusun sebuah karya ilmiah yang baik. Dan bagi tim pengabdian dapat mengukur sejauh mana pemahaman peerta pelatihan mengenai materi yang diberikan.

Dilihat dari pertanyaan-pertanyaan saat diskusi hal kebanyakan menjadi masalah adalah cara memilih judul yang baik dan menarik serta teknik memparafrase kalimat dari jurnal sumber untuk menghindari plagiarism.

Pada kegiatan ini, terdapat faktor penghambat kegiatan yaitu peserta senior yang kurang motivasi dalm menulis karena merasa waktu pensiun semakin dekat, adanya peserta yang kurang memahami teknologi sehingga butuh waktu untuk memahami materi yang diberikan. Sedangkan faktor pendukung kegiatan yaitu adanya dukungan dari Dinas terkait, tersedianya sarana dan prasarana kegiatan, disediakannya gedung untuk tempat pelatihan

\section{PENUTUP}

Ditinjau dari ketercapaian, kegiatan PPM ini terlaksana dengan dengan baik, hal ini dilihat dari beberapa peserta yang ternyata sudah mampu membuat artikel ilmiah yang baik. Peserta merasa dengan adanya pelatihan ini membuat peserta sadar bahwa menulis artikel ilmiah tidak "semenakutkan" seperti yang dibayangkan selama ini. Pada akhirnya disimpulkan bahwa kegiatan PPM ini tak hanya memberi ilmu mengenai cara membuat karya tulis ilmiah yang baik, tapi juga mampu menyadarkan dan memotivasi para peserta untuk berkarya melalui tulisan.

\section{UCAPAN TERIMA KASIH}

Tim PPM Universitas Jambi megucapkan terimakasih kepada kelompok Majelis Guru di Kota Sungai Penuh beserta Dinas Terkait atas partisipasi serta bantuannya sehingga kegiatan PPM ini berjalan dengan baik. Terimkasih juga disampikan kepada LPPM Univeritas Jambi atas pendanaan kegiatan pengabdian melalui dana DIPA PNBP Lembaga Penelitian dan Pengabdian Kepada Masyarakat Skema Pelaksanaan PPM Universitas Jambi.

\section{DAFTAR PUSTAKA}

Bhargava, M., Dubelaar, C., \& S. Ramaswami. (1994). Reconciling Diverse Measures of Performance: A Conceptual Frame Work and Test of a Methodology. Journal of Business Research. Vol. 31.

Dwiyanto, A. dkk. (2002). Reformasi Birokrasi di Indonesia. Yogyakarta: Pusat Studi Kependudukan dan Kebijakan, Universitas Gajah Mada.

Jasperson, J. Carter, P.E. Zmud, R.W. (2005). A Comprehensive Conceptualization of Post- Adoptive Behaviors Associated with Information Technology Enabled Work Systems. MIS Quarterly, Sept. 2005; 29,3. ABI/INFORM Global pg. 525. 
Levin, H.M. dan Schütze, 1983. H.G. (Ed.) Financing Recurrent Education, Strategies for Increasing Employement, Job Opportunities, and Productivity. Beverly Hills: Sage Publication.

Levin, H.M. (1983). Individual Entitlements. Dalam. Financing Recurrent Education, Strategies for Increasing Employement, Job Opportunities, and Productivity.

Murdick, R.G., Ross, J.E., Claggett, J.R. (1996). Sistem Informasi untuk Manajemen Modern (edisi ketiga/terjemah oleh Djamil). Jakarta: Penerbi Erlangga.

Nurkolis. (2003). Manajemen Berbasis Sekolah: Teori, Model, dan Aplikasi. Jakarta: Grasindo.

Slamet, R.A. \&, Deraman, A. (2008). Mengeliminasi Resistensi Masa menuju Berbudaya ICT pada Organisasi Publik Pendekatan Kurt Lewin. Dalam Makalahmakalah Sistem Informasi. Bandung : Penerbit Informatika. 
